\title{
Watermelon Fruit Disorders
}

Donald N. M aynard ${ }^{1}$ and D onald L. H opkins ${ }^{2}$

Additional indeX words. Citrulluslanatus disease, physiological disorder

Summary. Watermelon ( $C$ itrulluslanatus [Thunb.] M atsum $\& \mathbf{N}$ akai) fruit are affected by a number of preharvest disorders that may limit their marketability and thereby restrict economic returns to growers. Pathogenic diseases discussed include bacterial rind necrosis (E rwinia sp.), bacterial fruit blotch [A cidovorax avenae subsp. citrulli (Schaad et al.) Willems et al.], anthracnose [C dletotrichum orbi culare (Berk \& M ont.) Arx. syn. C. legenarium (Pass.) Ellis \& H alst], gummy stem blight/ black rot [D idymella bryoniae (Auersw.) R ehm], and phytophthora fruit rot (Phytophthora capsici L eonian). 0 ne insect-mediated disorder, rindworm damage is discussed. Physiological disorders considered are blossom-end rot, bottleneck, and sunburn. Additionally, cross stitch, greasy spot, and target cluster, disorders of unknown origin are discussed. E ach defect is shown in color for easy identification.

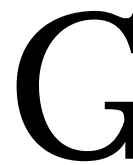

rowers and advisory personnel are often confronted with field problems that are difficult to diagnose. O ne such case in point are the many preharvest maladies affecting watermelon fruit. Although watermelon fields are frequently scouted for pest management purposes, fruit are not examined carefully until harvest begins. Accordingly, rapid diagnosis with accurate prediction of consumer acceptability is essential for marketing purposes. It is also important to know if there is likelihood of spread to unaffected fruit in transit. Where possible, we have included suggestions for amelioration of the problem, but have not included pesticide recommendations because of the advantage of current, local recommendations.

\section{Pathogenic diseases}

Bacterial rind necrosis. Rind necrosis was first reported in $\mathrm{H}$ awaii (I shii and Aragaki, 1960). Typical rind necrosis is characterized by a light brown, dry, and hard discoloration interspersed with lighter areas (Fig. 1). The disease develops in the rind and rarely extends into the flesh. O ccasionally the affected area is limited to the vascular bundles, but generally the discoloration spreads, sometimes affecting the entire rind. The causal organism was believed to be an Erwinia species.

The disease was first reported in the continental U nited States in several areas of Texas (Thomas, 1968). Fruit from some fields were completely free of the disease, whereas in other fields infected fruit ranged from few to many. Bacterial rind necrosis was often more severe in fields where plants were heavily infested with watermelon mosaic virus. This led to speculation that a common vector may facilitate the spread of both diseases. The causal organism again was narrowed down to an Erwinia species.

\footnotetext{
Florida Agricultural Experiment Station contribution R 06516. The cost of publishing this paper was defrayed in part by the payment of page charges. U nder postal regulations, this paper therefore must be hereby marked avertisement soley to indicate this fact.

${ }^{1}$ Professor, U niversity of Florida, $500760^{\text {th }}$ St. E., Bradenton, FL 34203-9324.

2Professor, U niversity of Florida, 5336 U niversity Ave., L eesburg, FL 34748-8232.
} 
Rind necrosisisa serious disease of watermelon that regularly occurs in California's I mperial Valley (Kontaxisand Kurupus, 1975). Results from several experiments to determine a causal agent were inconclusive.

In other experiments (H opkins and Elmstrom, 1977), the diversity of bacterial flora isolated from healthy and diseased fruit was similar except that enterobacteria were isolated more frequently from diseased than from healthy fruit. Erwinia, Pseudomonas, Enter obacter, and Bacillusisolated from symptomatic fruit caused rind necrosis at injection sites following inoculation.

Variation among varieties in susceptibility was reported in Florida (Elmstrom and H opkins, 1973 and H opkins and Elmstrom, 1974). O ver a3-year evaluation period, 'Sweet Princess' and 'Jubilee' were most tolerant, whereas 'K Iondike Blue Ribbon' and 'L ouisiana Q ueen' were most susceptible. The incidence of bacterial rind necrosisvaried from year to year. For example, 'Sweet Princess', the most tolerant variety, had $10.0 \%, 14.8 \%$ and $21.8 \%$ affected fruit in 1972, 1973, and 1974, respectively. 'KlondikeBlue Ribbon', themost susceptible variety, had $39.1 \%, 64.8 \%$ and $73.7 \%$ affected fruit in those years.

Some of these same varieties were evaluated in I mperial Valley of C alifornia (Kontaxis, 1976). 'Klondike Blue Ribbon' was the most tolerant variety and 'Sweet Princess' was intermediate in susceptibility. These results are at odds with those obtained in Florida.

To summarize, bacterial rind necrosis has been reported from several watermelon growing areas, Erwinia sp. most often has been associated with the diseased rind areas, other bacterial organisms isolated from either diseased or healthy fruit cause typical symptoms at inoculation sites, the incidence of the disease varies among varieties and growing seasons, and varieties may not always respond to the disease in the same way.

Watermelon bacterial rind necrosis appears to be genetically controlled but its frequency is affected by an interaction with environment. For the most part, varieties in use today appear not to be as susceptible as those used in the 1970s suggesting that watermelon breeders have been succesfful in selecting against the disease.

BaCterial FRUIT BLOTCH. Bacterial fruit blotch was first reported in the M arianna Islands (Wall and Santos, 1988). Symptoms on the surface of fruit begin as small, dark-green, water-soaked lesions that rapidly expand to cover much of the fruit surface in 7 to $10 \mathrm{~d}$ (Fig. 2). These surface lesions do not enlarge much after harvest of the fruit. I nitially, the lesions do not extend into the flesh of the melon. In advanced stages of lesion development, areasin the center of the lesion may turn brown, crack, and ooze a sticky, amber substance. Secondary organisms are ultimately responsible for decay and collapse of fruit.

The fruit blotch bacterium also produces foliar symptoms (Latin, 1996). First symptomsin watermelon seedlings consist of water-soaked areason thelower surface of cotyledonsand leaves, that becomenecrotic. In young seedlings, lesions in the hypocotyl can cause the collapse of the emerging plant. Leaf lesions are light brown to reddish-brown and often spread along the midrib of the leaf. Leaf lesions in the field usually are not very distinctive or severe and do not result in defoliation, but primarily serveasimportant reservoirs of bacteria for fruit infection.

Fruit blotch first occurred in commercial watermelon fieldsin theU nited Statesin Florida in the spring of 1989, with isolated severe outbreaksalso occurring in South Carolinaand Indiana as the season progressed (Latin and H opkins, 1995). In some fields, losses were greater than $90 \%$ Bacterial fruit blotch has been observed in the eastern U.S. every year since 1989, but usually occurs in only a few fields. Thedisease was most damaging in 1994, affecting thousands of acres of watermelons and causing extensive losses in at least 10 states.

The bacterium that causes fruit blotch of watermelon isA cidovoraxavenaesubsp. citrulli (formerly Psendomonaspseudoalcaligenessubsp. citrulli). The disease cycle usually begins with contaminated seed (L atin and H opkins, 1995). Much of the watermelon production in the U.S. is still from direct-seeded plants, but transplants are rapidly gaining in popularity. Bacteria from infested seed infect the developing seedling asthe cotyledons emerge from the seed coat. M ost transplant facilities employ overhead irrigation, which effectively splashdisperses bacteria to neighboring seedlings. This secondary spread in the transplant house can result in high numbers of infected seedlings reaching thefield. I n the field, symptom development and spread of A . avenaesubsp. citrulli on foliageand fruit ismost rapid during periods when the weather is hot and humid, with thundershowers (H opkins, 1993).

The ideal control of this disease is to prevent the introduction of the bacterium into thefield ( $L$ atin, 1996). Thiscan bedonebyuse of seeds that have tested negative for the presence of the fruit blotch bacterium, or use of plants from transplant houses in which there were no seedling symptoms of the fruit blotch disease. When symptoms are observed in the field, copper applications should begin as soon as possible and no later than the time of first flower (H opkins, 1991). Weekly applications of the highest recommended rate of coppercontaining fungicides has provided excellent control of bacterial fruit blotch of watermelon.

AnTHRACNOSE. On young fruit, anthracnose symptoms, caused by Colletotrichum orbiculare, consist of black spots which may 
result in abortion or malformation of themelon. O n older melons, small, water-soaked, elevated spots with greasy yellowish centers develop which givethefruit abumpy appearance. These raised areas later become sunken and are covered with pink spore masses (Fig. 3). The disease may develop and spread in transit.

Anthracnose symptoms can occur on all above-ground parts of the watermelon plant (Parris, 1952). L eaf lesions are brown to black, irregularly shaped, and usually limited by leaf veins. Stem lesions are often oval shaped and tan colored with a brown margin. Leaf and stem lesions serve as a source of spores for infection of the fruit.

Anthracnose was the most destructive disease of watermelon in the U nited States 40 to 50 years ago (Parris, 1952). While resistant varieties and improved control strategies have reduced losses to this disease, it isstill a relatively common disease of watermelon grown in humid regions throughout world. Colletotrichum orbiculare survives between crops on infected plant debris, volunteer plants and can be seedborne (Sitterly and Keinath, 1996a). Conidia of C . orbiculareare spread by wind, splashing rain, farm implements, and field workers. $\mathrm{H}$ umid, rainy weather isnecessary for infection to occur.

Resistanceto races 1 and 3 of $C$. orbiculare is present in several commercial watermelon varieties (Sitterly and Keinath, 1996a). Controls for anthracnose should include planting clean seed produced in areas where anthracnoseisnot aproblem and suppressing primary inoculum by deep plowing of crop residueafter harvest and by crop rotation. Chemical control can be attained with repeated application of protectant fungicides.

GUMMY STEM BLIGHT/BLACK ROT. O n fruit, this disease caused by Didymella bryoniae(anamorph Phoma cucurbitacearum (Fr.:Fr.) Sacc.) isknown asblack rot whereasthefoliage diseaseisknown as gummy stem blight. Small, water-soaked spots develop on watermelon fruit, enlarge, and exude gummy material (Fig. 4). As the symptoms develop, fruiting bodies of thefungus may appear as black specks on the lesions. In the tropics, fruit infection can occur through blossom scars and begin to decay inner fruit tissue, with no visible symptomson thesurface of the watermelon. The decay eventually will progress to thestem end and reach thesurface of the fruit (Sitterly and Keinath, 1996b).

Gummy stem blight can affect most above ground partsof thewatermelon plant(Sitterlyand Keinath, 1996b). Tan to dark brown spots occur on leavesand may rapidly enlargeasadark brown, water-soaked lesion until theentireleaf isblighted. Symptoms on petioles and stems first appear as water-soaked spots that develop into elongated, tan lesions. A brown, gummy exudate often is produced on the surface of the lesions. Older cankers appear corky and cracked with small fruiting bodies, usually pycnidia, that appear as blackspecks. Stemscan begirdled and plantskilled by crown lesions.

Black rot symptoms on watermelon fruit can develop in the field and result in significant losses to the grower. M ore frequently, severe decay of watermelon fruit from this disease occurs as a postharvest decay that develops during shipment to the marketplace, after infection occursin thefield. Thiscan beespecially severe when shipment occurs under warm, humid conditions. Black rot of watermelon was found to increase progressively from 45 to $75^{\circ} \mathrm{F}\left(7\right.$ to $24^{\circ} \mathrm{C}$ ) (Luepschen, 1961).

In the southern U .S. and other subtropical and tropical areas of the world, gummy stem blight is one of the most important diseases of watermelon. Didymella bryoniaesurvivesbetween seasons on crop debris in soil and on infected volunteer watermelon seedlingsand wild cucurbits. Primary infection sources for a watermelon field are contaminated seed, infected transplants, and airborne spores. Airborne ascospores were detected throughout the year in Florida with the peak occurring in June-July (Schenck, 1968). Ascospores appeared to be most important in the distant spread (field to field) of the pathogen; whereas, pycnidiospores, which are spread by splashing rain, were more involved in the local plant to plant spread within afield. The pathogen often persists through adverse weather as perithecia on the crowns of watermelon plants. Warm, humid conditions favor the development of gummy stem blight and most rapid disease development occurs with frequent rains (Schenck, 1969). Free moisture on leaves for at least $1 \mathrm{~h}$ is required for infection and further continuousleaf wetness is needed for lesion expansion.

No commercially acceptable watermelon varieties with resistanceto gummy stem blight are available (Sitterly and Keinath, 1996b). Controls for gummy stem blight should include cultural practicesto reduce the primary infection as much as possible, such as using seed that have tested negative for $D$. bryoniae, and using a minimum of 2-year rotation cycles between cucurbit crops. Practices that minimize leaf wetness in the transplant house and field should be used when possible, such as drip rather than overhead irrigation. Satisfactory chemical control can be obtained by regular applications of protectant fungicides (Keinath, 1995).

Phitophthora frutr rot. Symptoms begin as a water-soaked, often depressed, spot (Fig. 5). Frequently, thearea of thefruit in contact with the moist ground is affected first, but symptoms also can develop on theupper surface, following rain or overhead irrigation which provides splashing wa ter to disperse the pathogen. In older lesions, a mass of white mycelium that contains sporangia may develop. I nfected fruit can decay rapidly and collapse. Fruit decay may continue after harvest.

Phytophthora fruit rot is caused by Phytoph- 

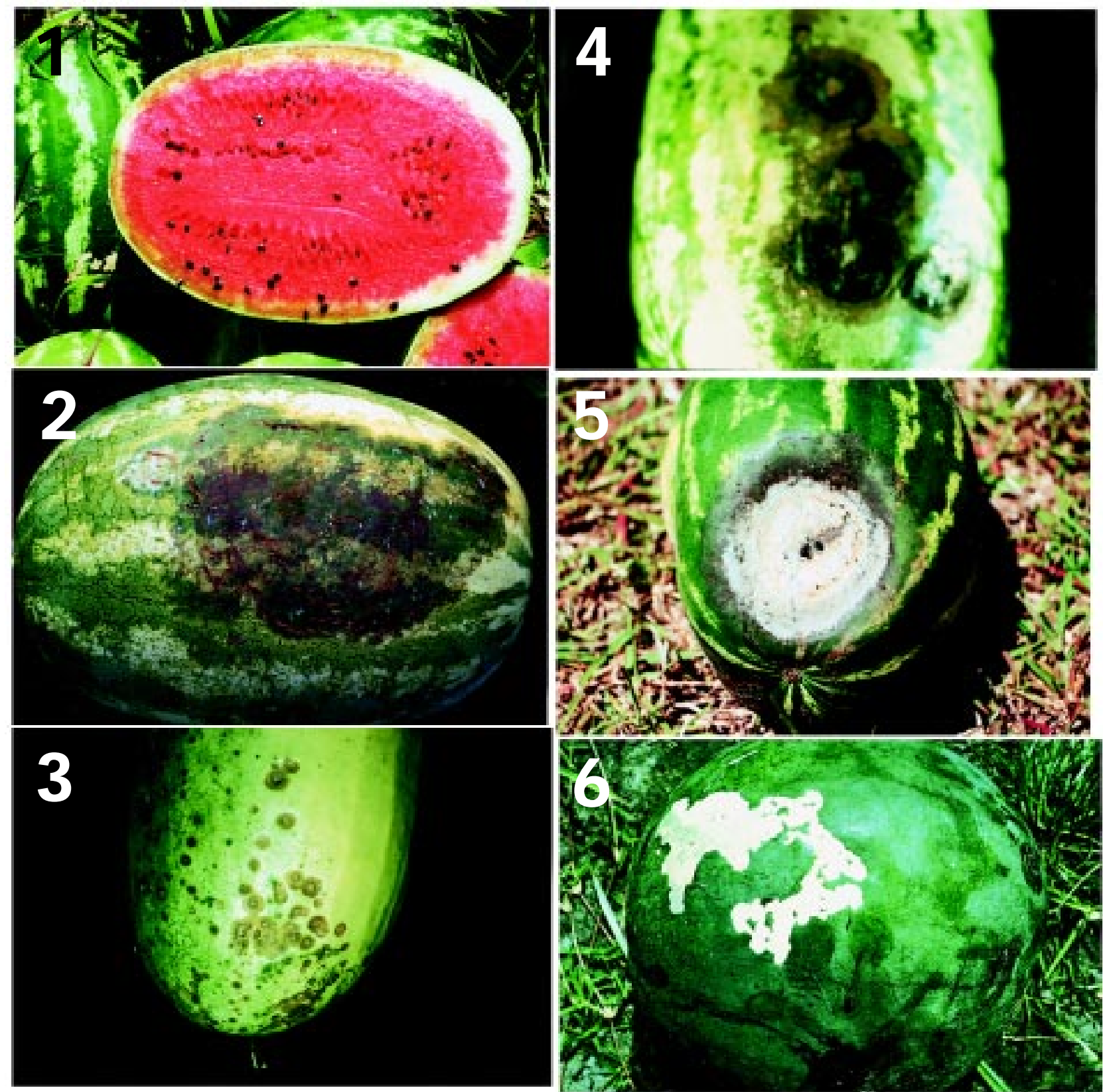

Figs. 1-6. Bacterial rind necrosis, bacterial fruit blotch, anthracnose, gummy stem blight/black rot, phytophthora fruit rot, and rindworm damage.

thora capsid and other Phytophthora sp. A widerangeof vegetablecrops, including all cucurbits, are susceptible to this fruit rot. All parts of the plant can be attacked, producing water-soaked lesionson leaves, stem lesions, and dieback of shoot tips in watermelon (M cGovern et al., 1993). Commonly, crown rot causes entire plant wilting and death (Robertsand M CG overn, 1998).

The fungus survives for at least 2 yearsin thesoil ( $M$ cG rath, 1996). Spores of $P$. capsici are spread by wind and water, in infected transplants, and through contaminated soil and equipment (M cG overn et al., 1998). Surface moistureisrequired for motilezoospores of $P$. capsici to reach and invade the host. Therefore, phytophthora fruit rot is most severe in warm, wet weather and in low, water-logged areas of fields.

For disease control, rotation with nonhost crops is recommended, avoiding rotationswith pepper, tomato, eggplant, cocoa, and macadamia(M cG rath, 1996). M anagement of soil moistureby selecting well-drained fields, avoiding low-lying fields, and not overirrigating is an effective management strategy. Other good management practices to limit phytophthora fruit rot include the elimination of volunteer crop plantsand weeds, roguing infected watermelon plants, and decontaminating equipment (M cGovern et al., 1998). When combined with good cultural practices, fumigation and preventivefungicidesmay help suppress disease.

\section{Insect-mediated damage}

RINDWorm. I nsect larvae that feed on watermelon rinds are generically referred to as rindworms regardless of their specific identities. Their feeding results in irregular trails over the rind surface (Fig. 6) which may limit salability when severe or when market conditions are poor. The most troublesome insect species that have been implicated with rindworm damageincludethecabbage looper (Trichoplusia ni H ubner), 

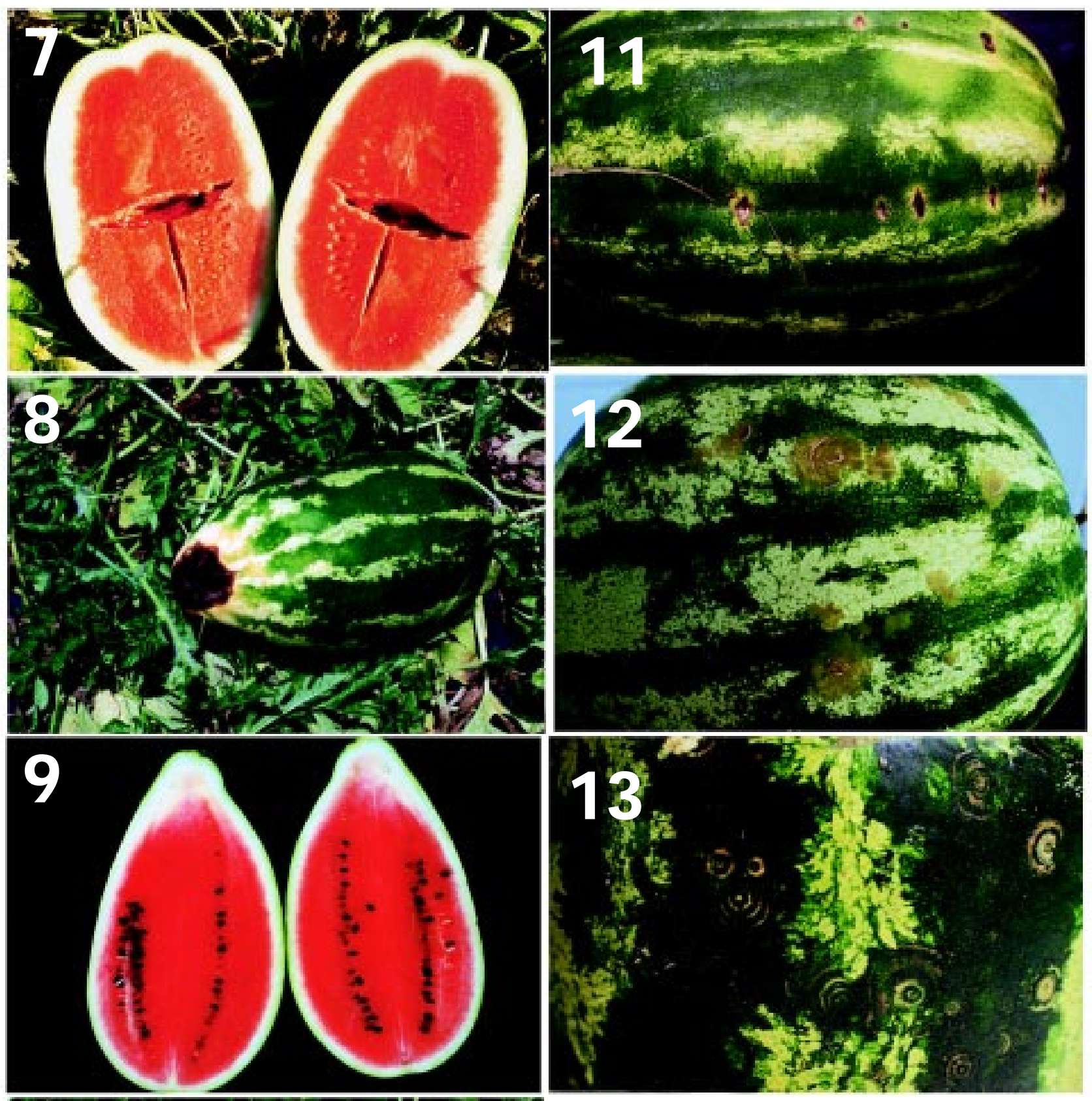

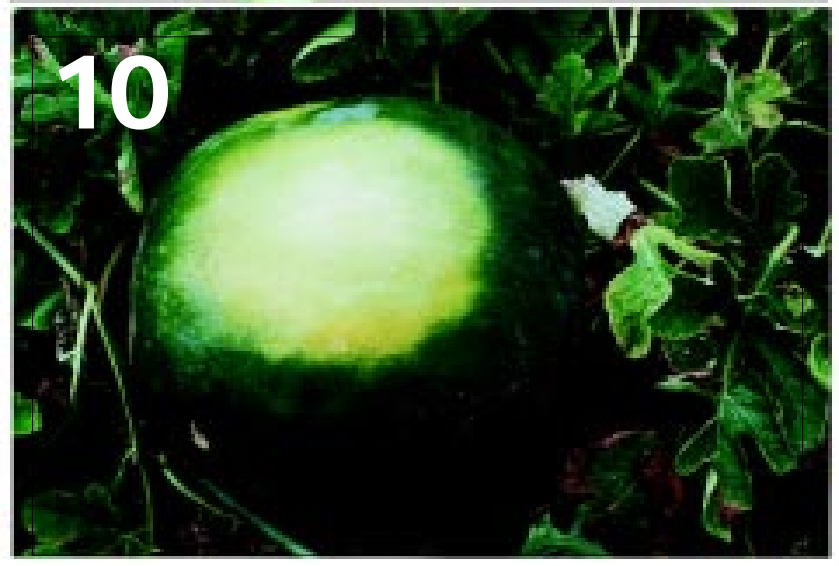

tobacco budworm ( $\mathrm{H}$ eliothis virescens Fabricius), and granulate cutworm (Feltia subterranea Fabricius). Other species occasionallymaycause rind damage. Successful rindworm managementhasbeen achieved by natural control with native parasites early in the season and by chemical means later in the season (Adlerz, 1971, 1975).

Figs.7-13. H ollowheart, blossomend rot, bottleneck, sunburn, cross stitch, greasy spot, and target cluster.

\section{Physiological disorders}

Hollowheart. This disorder is manifested by the separation of flesh within the fruit (Fig. 7) . It occurs in every production area but frequency and severity vary considerably among areas and seasons. O ccasionally, however, loads are rejected because of hollowheart. As far as we are aware, there is no estimate of the economic impact of hollowheart although it is certain to be significant. It is very difficult to externallydistinguish hollowheart fruit from fruit with an intact heart although the former tend to be somewhat asymmetrical. N oninvasive detection of hollowheart has been attempted by magnetic resonanceimaging ( $\mathrm{MRI}$ ), mammography, fluoroscopy, ultrasound, and xerography ( $\mathrm{M}$ cC uistion et al., 1995). Following preliminary evaluation, fluoroscopy wasfound to bemost 
effective for distinguishing hollowheart. Operators were able to identify 20 of 23 melons with hollowheart using one view. D etection improved to 22 of 23 fruit with hollowheart when fruit were viewed from two directions. The authors suggest that commercial detection with fluoroscopy could be incorporated into packinghouse operations. The Japanese are already using nuclear magnetic resonance (N M R) in T ottori Prefecture for simultaneous determination of solublesolidsand hollowheart (D. M aynard, personal observation).

M ost watermelon expertsagree that there is a higher incidence of hollowheart in crown-set fruit than in lateral-set fruit, that triploid (seedless) varieties have more hollowheart than diploid (seeded) varieties, and that there are differences among varietiesin hollowheart susceptibility. $\mathrm{Be}$ yond that, there ismuch speculation asto therole of water and fertilizer management, temperature, pollination, and other factors.

Because of the difficulty in understanding the cause of hollowheart, little research has been reported. R esultsobtained in J apan (Kano, 1993) confirm that hollowheart occurs more frequently in crown-set (7th to 8th node) than in lateral-set (20th node) fruit. The crown-set fruit had fewer but larger cells than the lateralset fruit; they al so had larger intercellular spaces than thelateral-set fruit. Accordingly, cell separation occurs because the fewer, less compacted cells in the crown-set fruit cannot keep pace with the expansion rate of the rind. When growth rate was depressed by defoliation, the inner cell growth rate did keep pace with the expansion of the rind and hollowheart did not occur. These results agree with the notion held by some that watermelon plants that are "forced" are morelikely to produce fruit with hollowheart (Rubatzky and Yamaguchi, 1997; Wien, 1997).

In preliminaryexperiments(M aynard, 1995), 'J ack of H earts', a triploid variety, had $14 \%$ of its fruit affected by hollowheart whereas 'Sangria', a diploid variety, had $5 \%$ hollowheart fruit. The averagecell separationsin 'J ack of $\mathrm{H}$ earts' fruitwas 0.21 inch $(0.5 \mathrm{~cm})$ in diameter whereas the cell separation wasonly 0.02 inch $(0.05 \mathrm{~cm})$ in diameter in 'Sangria' fruit. H ollowheart in 'Jack of $\mathrm{H}$ earts' was more frequent and severe when fertilized with $130 \mathrm{~N}-25 \mathrm{P}-150 \mathrm{~K} \mathrm{lb} /$ acre(145N $29 \mathrm{P}-168 \mathrm{~K} \mathrm{~kg} \cdot \mathrm{ha}^{-1}$ ) than with various combinations of higher $\mathrm{N}$ and $\mathrm{K}$ rates. $\mathrm{No}$ relationship between fruit age (days after pollination) and hollowheart was established. H owever, earlier studies by EImstrom et al., (1995) showed that there was a low incidence and severity of hollowheart in 'Jack of $\mathrm{H}$ earts' and 'Crimson Sweet' watermelon at 5 and $12 \mathrm{~d}$ postpollination, but much greater hollowheart at 19, 26, and $33 \mathrm{~d}$ after pollination.

BLossom-end ROT. Symptoms begin as a softening and shriveling of the blossom end of partially grown fruit and progress to a darkbrown, sunken, leathery lesion (Fig. 8). Varieties producing elongated fruit are more susceptible to blossom-end rot than those producing round fruit (H ammouda, 1987).

The incidence of the disorder is increased under low calcium regimes (Waters and $\mathrm{N}$ ettles, 1961). Recommendations for control of blossom-end rot include liming of soil according to soil test results and maintenance of an adequate, uniform soil moisturethrough irrigation management (Kucharek and H opkins 1992).

BotTleneCK. Constricted growth at the stem end of the fruit characterizesthis disorder (Fig. 9). It is attributed to inadequate pollination either because of a low bee population or to poor conditionsfor bee activity such ascold, wet, or windy weather. The cause of the misshapen fruit can be verified by a cut fruit which will show an absence of seed at the stem end of the watermelon (J ohnson, 1992).

SunBurn. This disorder appears on the upper fruit surface as a gray area where the rind pigment has been destroyed (Fig. 10). $\mathrm{H}$ igh temperature and high light intensity together are essential for expression of sunburn in cucumber and pepper fruits (Rabinowitch et al., 1986), but the precise cause of sunburn on watermelon fruit has not been determined. The average watermelon rind temperature of several varietiesreached $107^{\circ} \mathrm{F}\left(41.6^{\circ} \mathrm{C}\right)$ in the sun and was $97^{\circ} \mathrm{F}\left(36.1^{\circ} \mathrm{C}\right)$ in the shade when air temperaturewas $89^{\circ} \mathrm{F}\left(31.9^{\circ} \mathrm{C}\right)(\mathrm{M}$ aynard, 1991 unpublished). Sunburn damage may be avoided somewhat byselection of varieties with light colored rinds which seem to be less subject to sunburn than dark-rinded varieties. The best means of circumventing sunburn damage, however, isto provide conditionsfor good vine growth which shades the watermelon fruit.

\section{Disorders of unknown origin}

CRoss StrTCH. This disorder appears as a series of 0.5 to 1 -inch (1 to $2-\mathrm{cm}$ ) long necrotic wounds that are perpendicular to the longitudinal axis of the fruit (Fig. 11). It was observed in I ndianain thelate 1980sand early 1990sand in Florida in 1990 where the name was coined (Latin, 1993).

GREASYSPOT. Relativelyinconspicuousraised, circular, olive-green areas on the rind surface characterizethisdisorder first described in Florida (Fig. 12). G reasy spot occursrarelyand isthought not to be of economic concern (L atin, 1993).

TARGet cluster. Distinctive target-like configurations occur on the rind surface, usually in clusters of three or more targets (L atin, 1993). It has been suggested, because of their unique appearance (Fig. 13), that the causal organism may be a ringspot virus, but this has not been confirmed. The disorder is not common but it has been observed in Florida and in Australia (D N M , personal observations). 


\section{Literature cited}

Adlerz, W.C. 1971. Cabbage looper control on watermelon at Leesburg, 1968-1970. Proc. Fla. H ort. Soc. 84:145-146.

Adlerz, W.C. 1975. N atural control of three rindworm species and chemical control of the granulate cutworm, Feltis subterranea, on watermelon. Proc. Fla. State. H ort. 88:204-207.

Elmstrom, G.W. and D.L. Hopkins. 1973. Variable susceptibility to bacterial rind necrosis in watermelon. H ortScience 8:32.

EImstrom, G.W., F. M cC uistion, J r., and D .N . M aynard. 1995. Incidence and severity of watermelon (Citrullus lanatus) hollowheart. H ortScience 30:427 (abstr.).

$\mathrm{H}$ ammouda, A.M. 1987. Blossom-end rot of watermelon in the southern region of $\mathrm{O}$ man (D hofan). J. Agr. Sci. Camb. 108:667-669.

H opkins, D.L. 1991. C hemical control of bacterial fruit blotch of watermelon. Proc. Fla. State Hort. Soc. 104:270-272

H opkins, D.L. 1993. Field spread of bacterial fruit blotch of watermelon. Phytopathology, 83:466 (abstr.).

H opkins, D.L. and G.W. Elmstrom. 1974. Severity of bacterial rind necrosisin watermelon cultivars in Florida. Proc. Fla. State H ort. Soc. 87:184-187.

H opkins, D.L. and G.W. Elmstrom. 1977. Etiology of watermelon rind necrosis. Phytopathology 67:961-964.

I shii, M . and M. Aragaki. 1960. Bacterial rind necrosis of watermelon. Plant Dis. R ptr. 44:761-763.

Johnson, F.A. 1992. Pollination, p. 9-10. In: D.N. $M$ aynard (ed.). Watermelon production guidefor Florida. Fla. Coop. Ext. Serv. SP 113.

Kano, Y. 1993. Relationship between the occurrence of hollowing in watermelon and the size and number of fruit cells and intercellular air spaces. J. J pn. Soc. H ort. Sci. 62:103-112.

Keinath, A.P. 1995. Fungicide timing for optimum management of gummy stem blight epidemics on watermelon. Plant Dis. 79:354-358.

Kontaxis, D.G. 1976. Rind necrosis in watermelon cultivars. Calif. Agr. (Feb.):22.

Kontaxis, D.G. and T. Kurupus. 1975. Watermelon rind necrosis in I mperial Valley. Calif. Agr. (Sept.):14-15.

Kucharek, T.A. and D.L. H opkins. 1992. Disease management, p. 39-40. In: D.N. M aynard (ed.). Watermelon production guide for Florida. Fla. Coop. Ext. Serv. SP 113.

Latin, R.X. 1993. D iseases and pests of muskmelons and watermelons. Purdue U niv. Coop. Ext. Serv. BP-44.

L atin, R.X. 1996. Bacterial fruit blotch, p. 34-35 In:T.A. Zitter, D.L. H opkins, and C.E. Thomas (eds.). Compendium of cucurbit diseases. APS Press, St. Paul, M inn.

Latin, R.X. and D.L. Hopkins. 1995. Bacterial fruit blotch of watermelon: The hypothetical exam question becomes reality. Plant $D$ is. 79:761-765.

Luepschen, N.S. 1961. The development of mycosphaerella black rot and Pellicularia rolfsi rot of watermelons at various temperatures. Plant $D$ is. Rptr. 45:557-559.
M aynard, D.N . 1995. Watermelon hollowheart, spring 1995. GCREC (U niv. Fla.) Res. Rpt. BRA1995-28.

M cCuistion, Jr., F.T., G.W. Elmstrom, P. Abbott, B. Steinbach, B. Faile, N. Ackerman, L. N euwirth, and C. Spencer. 1995. Fluoroscopy as a non-invasive method for detecting hollowheart and seeds in watermelon fruit, p. 140-141. In: G.E. Lester and J.R. Dunlap (eds.). Proceedings Cucurbitaceae ' 94 . G ateway Printing and O ffice Supply, Edinburg, Tex.

M cGovern, R.J., J.P. J ones, D.J. M itchell, R.A. Pluim, and P.R. Gilreath. 1993. Severe outbreak of phytophthora blight and fruit rot of cucurbits in Florida. Phytopathology 83:1388 (abstr.).

M cG overn, R.J ., P.D. Roberts, T.A. Kucharek, and P.R. Gilreath. 1998. Phytophthora capsici: N ew problems from an old enemy. Proc. Fla. T omato I nst. U niv. of Fla. PRO 111:9-16.

M CG rath, M .T . 1996. Phytophthora fruit rot, p. 53-54. In: T.A. Zitter, D.L. H opkins, and C.E. Thomas (eds.). Compendium of cucurbit diseases. APS Press, St. Paul, $M$ inn.

Parris, G.K. 1952. D iseases of watermelon. Fla. Agr. Expt. Sta. Bul. 491.

Roberts, P.D. and R.J. M cGovern. 1998. Phytophthora blight cause significant losses to spring vegetable crops. Fla. Agr. Conf. Trade Show Proc. p. 31-32.

Rabinowitch, H.D., B. Ben-D avid, and M. Friedman. 1986. Light is essential for sunscaled induction in Cucumber and pepper fruits, whereas head conditioning provides protection. Scientia H ort. 29:21-29.

Rubatzky, V.E. and M. Yamaguchi. 1997. World vegetables: principles, production, and nutritive value. 2nd ed. Chapman and $\mathrm{H}$ all, $\mathrm{N}$ ew York.

Schenck, N.C. 1968. Incidence of airbornefungusspores over watermelon fieldsin Florida. Phytopathology 58:9194

Schenck, N.C. 1969. An epidemiological comparison of downy mildew and gummy stem blight diseases on watermelon. Proc. Fla. State H ort. Soc. 81:151-154.

Sitterly, W.R. and A.P. Keinath. 1996a. Anthracnose, p. 24-25. In: T.A. Zitter, D.L. H opkins, and C.E. Thomas (eds.). Compendium of cucurbit diseases. APS Press, St. Paul, Minn.

Sitterly, W.R. and A.P. Keinath. 1996b. Gummy stem blight, p. 27-28. In: T.A. Zitter, D.L. H opkins, and C.E. Thomas (eds.). Compendium of cucurbit diseases. APS Press, St. Paul, M inn.

Thomas, C.E. 1968. Bacterial rind necrosis of watermelon in south Texas. Plant D is. R ptr. 52:375-377.

Wall, G.C. and V.M. Santos. 1988. A new bacterial disease of watermel on in the $\mathrm{M}$ ariana I slands. Phytopathology 78:1605 (abstr.).

Waters, W.E. and V.F. N ettles. 1961. The effect of calcium on growth responses, sex expression, fruit responses, and chemical composition of the $C$ harleston Gray watermelon. Proc. Amer. Soc. H ort. Sci. 77:508-512

Wien, H.C. 1997. The cucurbits: cucumber, melon, squash, pumpkin, p. 345-386. In: H.C. Wien (ed.). The physiology of vegetable crops. CAB Intl., N ew York. 